\title{
IT students' perceptions on e-learning: a preliminary survey at University of Colombo
}

Priyangika, D.S ${ }^{1}$ and Jayasundara, C.C. ${ }^{2}$

\begin{abstract}
There is a trend in universities to utilize e-learning to improve the quality of learning activities of campus based students. The objective of the study was to find out the IT students' perceptions towards e-learning. The population of the study consisted of five hundred and twenty five students. Stratified random sampling was used to select the sample elements from the study population. A questionnaire was administered to two hundred and twenty six students. A total of hundred and fourty five complete questionnaires were selected for the analysis. More fourth year students are uncertain on the helpfulness of the course management systems in improving exam results. More students who use computer facilities only at the University and students who do not have a computer have negative perception on their ability to learn in an elearning environment, usefulness of online resources for learning and the availability of opportunities to share and discuss subject matters with other students.
\end{abstract}

Key Words: E-learning, Students' Perceptions

\section{Introduction}

E-learning, using computers for learning is the current trend in universities all over the world. The term, E-learning is defined in different ways in terms of its practice. According to Mering \& Robbie (2004) e-learning is a term which covers various approaches to learning such as purely online, blended learning, synchronous, asynchronous, web based, computer based etc. As expressed by Secker (2004) e-learning covers wide range of applications that ranges from on-line to off-line including "... online learning, learning on the Net/Internet, web based learning, learning using Virtual Learning Environment (VLE),

\footnotetext{
${ }^{1}$ Assistant Librarian, University of Kelaniya, Sri Lanka. Email: subhanee@kln.ac.lk

${ }^{2}$ Deputy Librarian, University of Colombo, Sri Lanka. Email: chaminda@lib.cmb.ac.lk
} 
Journal of the University Librarians Association, Sri Lanka, Vol. 16, Issue 2, July 2012

CD-ROM learning, computer based learning, E-mailing, using mailing lists, conferencing boards, discussion rooms, one to one chat etc". These new forms of delivery methods offer many advantages to learners. Mering \& Robbie (2004) highlight that e-learning offers greater flexibility, portability, convenience, on demand access, increased collaboration and social interaction which are very essential to the learning process. Course materials are accessible to 24 hours a day, 7 days a week at home, office or even on the road. These advantages offer learning opportunities for disabled or remote students. E-learning allows learning to be shared with a wide audience through the tools and systems such as Internet, Intranet, email, chat, discussion groups, wikis, blogs etc. Chadha \& Kumail (2003) confirm that e-learning is a very good opportunity for getting feedback. In a classroom based environment giving as well as hearing negative feedback is embarrassing. E-learning provides information services customized to students' needs, their knowledge, expertise and experience. It facilitates to skip things that are already known or students can go through any topic repetitively. In Sri Lankan context e-learning is employed to increase the access to higher education and improve the quality of learning in campus-based students. Therefore, the objective of the study was to find out perception of IT students' towards e-learning.

\section{Research Methodology}

The case study approach was used for the study. The study was conducted in the University of Colombo in 2009. The study population consisted of the second year, third year and fourth year students who were following Bachelors Degree in Information and Communication Technology (ICT) and Computer Science (CS). These students have experience in online learning as well as traditional learning. Altogether, target population consisted of five hundred and twenty five students. Stratified random sampling was used to select the sample elements from student population. The student population was stratified into two groups according to the degree program following, and it was further divided into sub groups based on the year of study. The number of students in the sample was determined by the table created by Krejcie \& Morgan (1970) for determining sample 
Journal of the University Librarians Association, Sri Lanka, Vol. 16, Issue 2, July 2012

size for research activities. The sample size was two hundred and twenty six (Table 1).

Table 1: Representation of the students in each stratum

\begin{tabular}{c|ccc}
\hline Course & Year & No of Students & No of students inthe sample \\
\hline \multirow{4}{*}{ CS } & 2 & 148 & 64 \\
& 3 & 157 & 67 \\
& 4 & 40 & 17 \\
ICT & 2 & 84 & 36 \\
& 3 & 76 & 33 \\
& 4 & 20 & 9 \\
& Total & 525 & 226 \\
\hline
\end{tabular}

The questionnaires were used to collect data from students. The questionnaire consisted of sixteen statements which were suggested by the literature and developed by the researcher. Using these statements students' were asked to state their perceptions on elearning. The perceptions were measured on a 5-point Likert scale ranges from strongly disagree to strongly agree. Students' demographics information such as degree enrolled, year of study, gender, hours spend on the Course Management System (CMS), the place of stay during study, availability of computer and Internet facilities and ownership of a computer were collected. The cleaned data was coded and entered into the computer using standard statistical program called SPSS (Statistical Package for the Social Sciences) for Windows release 13.0. Cross tabulations and Chi-square tests were run between perceptions and students' demographic variables to identify the relationships. Post-hoc analyses for chi-square test of independence were run to identify where the variation actually occurred.

\section{Data Analysis and Discussion}

One hundred and seventy seven students have responded the questionnaires at the rate of $78.3 \%$. To preserve the sample size requirements for the chi-square test of independence, incomplete questionnaires were removed and only hundred and fourty 
Journal of the University Librarians Association, Sri Lanka, Vol. 16, Issue 2, July 2012

five questionnaires were selected for the analysis. The demographics of the participants are presented in Appendix 1. Table 2 provides the distribution of students' perceptions of e-learning.

Table 2: Students' perceptions of e-learning

SD- Strongly Disagree, D-Disagree, U-Undecided, A-Agree, SA-Strongly Agree

\begin{tabular}{|c|c|c|c|c|c|}
\hline & & SD/D & $\mathbf{U}$ & $\mathrm{A} / \mathrm{SA}$ & Total \\
\hline S1 & E-learning facilitates learning & (21) $14.5 \%$ & (4) $2.8 \%$ & (120) & 145 \\
\hline S2 & $\begin{array}{l}\text { E-learning is a tool that improves the quality of } \\
\text { face to face teaching. }\end{array}$ & (33) $22.8 \%$ & $\begin{array}{l}(48) \\
33.1 \%\end{array}$ & (64) $44.1 \%$ & 145 \\
\hline S3 & E-learning is popular among students & (46) $31.7 \%$ & (31) & (68) $46.9 \%$ & 145 \\
\hline S4 & $\begin{array}{l}\text { E-learning makes learning environment too } \\
\text { complicated. }\end{array}$ & $\begin{array}{l}(76) \\
52.4 \%\end{array}$ & $\begin{array}{l}(40) \\
27.6 \%\end{array}$ & (29) $20.0 \%$ & 145 \\
\hline S5 & $\begin{array}{l}\text { E-learning could benefit only several groups of } \\
\text { students. }\end{array}$ & (41) $28.3 \%$ & $\begin{array}{l}(26) \\
17.9 \%\end{array}$ & (78) $53.8 \%$ & 145 \\
\hline S6 & $\begin{array}{l}\text { E-learning helps me to learn independently } \\
\text { and self-motivated. }\end{array}$ & (27) $18.6 \%$ & $\begin{array}{l}(23) \\
15.9 \%\end{array}$ & (95) $65.5 \%$ & 145 \\
\hline S7 & The content of a course can leam effectively & (55) $37.9 \%$ & (30) & $(60) 41.4 \%$ & 145 \\
\hline S8 & $\begin{array}{l}\text { At present I have skills to learn in an e-learning } \\
\text { environment. }\end{array}$ & (32) $22.1 \%$ & $\begin{array}{l}(25) \\
17.2 \%\end{array}$ & (88) $60.7 \%$ & 145 \\
\hline S9 & Online resources are valuable for learning & (17) $11.7 \%$ & (16) & (112) & 145 \\
\hline S10 & I prefer online submission of assignments & (24) $16.6 \%$ & (21) & $(100)$ & 145 \\
\hline S11 & Taking online exams are convenient & (38) $26.2 \%$ & (33) & (74) $51.0 \%$ & 145 \\
\hline S12 & $\begin{array}{l}\text { The Course Management Systems (CMS) } \\
\text { helps in improving exam grades }\end{array}$ & (25) $17.2 \%$ & $\begin{array}{l}(55) \\
37.9 \%\end{array}$ & (65) $44.8 \%$ & 145 \\
\hline S13 & $\begin{array}{l}\text { It is easy to get prompt feedback through } \\
\text { onlinecontact oflecturers. }\end{array}$ & $\begin{array}{l}(30) \\
20.7 \%\end{array}$ & $\begin{array}{l}(41) \\
28.3 \%\end{array}$ & (74) $51.0 \%$ & 145 \\
\hline S14 & $\begin{array}{l}\text { E-learning provides opportunities to share and } \\
\text { discuss subjectmatters. }\end{array}$ & (26) $17.9 \%$ & $\begin{array}{l}(21) \\
14.5 \%\end{array}$ & (98) $67.6 \%$ & 145 \\
\hline S15 & Overall I haveenjoyed leaming online. & (35) $24.1 \%$ & (25) & (85) $58.6 \%$ & 145 \\
\hline S16 & $\begin{array}{l}\text { I would like to take fully online courses in the } \\
\text { future. }\end{array}$ & (66) $45.5 \%$ & $\begin{array}{l}(30) \\
20.7 \%\end{array}$ & (49) $33.8 \%$ & 145 \\
\hline
\end{tabular}


Journal of the University Librarians Association, Sri Lanka, Vol. 16, Issue 2, July 2012

Students' perceptions of e-learning are depicted in a bar chart in Figure 1.

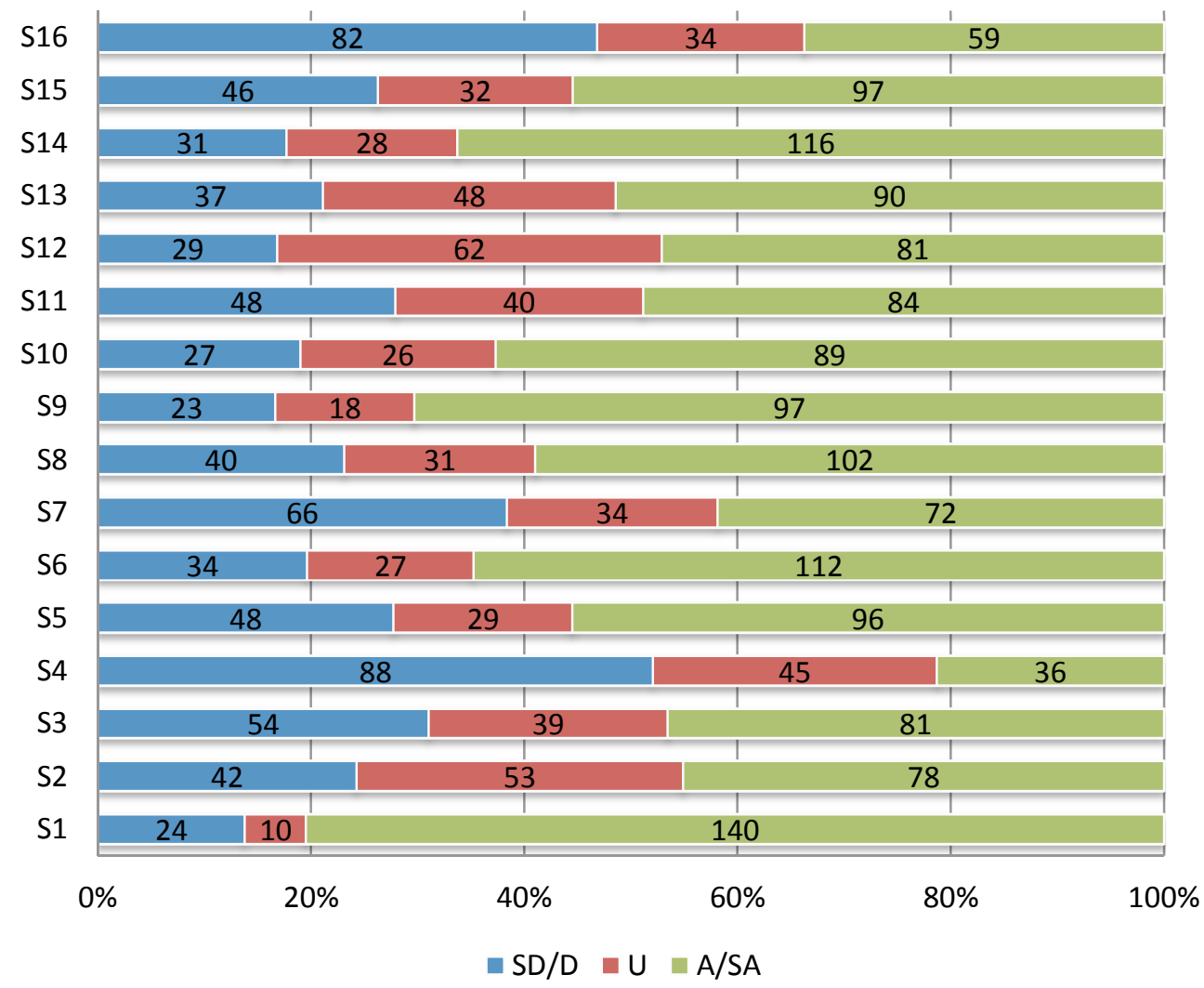

Figure 1: Students' perceptions of e-learning

\section{Relationship between Course Enrolled vs Students' Perceptions}

Eighty five 85 (58.6\%) Computer Science students and sixty (41.4\%) Information and Communication Technology students participated in the survey. The cross tabulations were run to determine the association between course enrolled and students' perceptions for the sixteen statements starting from "E-learning facilitates learning" to "I would like to take fully online course in the future". Chi-square test of independence was used to see if there are any differences in responses by ICT and CS students to all the statements. The chi-square result found to be statistically significant with $p<0.05$ where chi-square value is 6.209 and $p$-value $=0.045$ (Table 3). 
Table 3: 'Degree enrolled*E-learning is popular among students' cross tabulation \& $\chi 2$ - test result for the cross tabulation

\begin{tabular}{l|ccc|c}
\hline \multirow{2}{*}{ Degree enrolled } & \multicolumn{3}{|c|}{$\begin{array}{c}\text { Eleaming is popular among } \\
\text { students }\end{array}$} & \multirow{2}{*}{ Total } \\
\cline { 2 - 4 } & Disagree & Undecided & Agree & \\
\hline CS & 33 & 19 & 33 & 85 \\
ICT & 13 & 12 & 35 & 60 \\
Total & 46 & 31 & 68 & 145 \\
\hline Chi - Square $(\chi \mathbf{2})=\mathbf{6 . 2 0 9}$ & $\mathrm{df}=2$ & P-value=0.045 \\
\hline
\end{tabular}

The chi square test supported that the existence of relationship between course enrolled and perception on the popularity of e-learning among students. To determine which cell or cells caused the relationship, chi square test of independence was computed with standardized residuals. For the post hoc test, 0.05 was used as the alpha and \pm 1.96 as the critical values in the research. The perceptions on the popularity of e-learning among students depend to some extent on course enrolled. The effect is quite weak. There were no any cells with statistically significant standardized residuals.

\section{Relationship between Year of Study vs Students' Perceptions}

Majority of the participants (69) $47.6 \%$ were second year students. The analysis indicates that the year of study and the responses to the statements "E-learning could benefit only several groups of students" and "The Course Management Systems help in improving exam grades" are correlated. The chi-square test results found to be statistically significant with $p<0.05$. The chi square values are 9.897 and 13.767 where $p$-values are 0.042 and 0.008 respectively (Table 4 and Table 5). 
Table 4: 'Year of study*E-learning could benefit only several group of students' cross tabulation and $\chi 2$-test result for the cross tabulation

\begin{tabular}{|c|c|c|c|c|}
\hline \multirow[t]{2}{*}{ Year ofstudy } & \multicolumn{3}{|c|}{$\begin{array}{c}\text { E-leaming could benefit only several group of } \\
\text { students }\end{array}$} & \multirow[t]{2}{*}{ Total } \\
\hline & Disagree & Undecided & Agree & \\
\hline Second & 13 & 16 & 40 & 69 \\
\hline Third & 17 & 9 & 28 & 54 \\
\hline Fourth & 11 & 1 & 10 & 22 \\
\hline Total & 41 & 26 & 78 & 145 \\
\hline Chi - Square $(\chi 2)=9.897$ & $d f=4$ & -value $=0.042$ & & \\
\hline
\end{tabular}

Table 5: 'Year of study*The CMS help in improving exam grades' cross tabulation \& $\chi 2$ - test result for the cross tabulation

\begin{tabular}{l|c|c|c|c}
\hline \multirow{2}{*}{ Year of study } & \multicolumn{2}{|c|}{ The CMS help in improving exam grades } & \multirow{2}{*}{ Total } \\
\cline { 2 - 4 } & Disagree & Undecided & Agree & \\
\hline Second & 9 & 22 & 38 & 69 \\
Third & 13 & 18 & 23 & 54 \\
Fourth & 3 & 15 & 4 & 22 \\
Total & $\mathbf{2 5}$ & $\mathbf{5 5}$ & $\mathbf{6 5}$ & $\mathbf{1 4 5}$ \\
\hline
\end{tabular}

Chi - Square $(\chi 2)=13.767 \quad \mathrm{df}=4 \quad$ P-value $=0.008$

The post-hoc tests revealed that the effect of the cell(s) for the relationship of year of study and perceptions for "e-learning could benefit only several groups of students" is weak. The perceptions depend to some extent on year of study. The only one cell on the 'Undecided' row has contributed to the chi-square relationship between year of study and the perceptions on helpfulness of course management systems in improving exam grades (Appendix 2-Table I). More fourth year students are uncertain on the helpfulness of the course management systems in improving exam grades than expected.

\section{Relationship between Gender vs Students' Perceptions}

Among the responded students (95) 65.5\% were male participants and (50) $34.5 \%$ were female participants. The cross tabulations run between gender and students' perceptions indicated that there is a difference between male and female students' responses for the statement "E-learning provides opportunities to share and discuss subject matters with 
Journal of the University Librarians Association, Sri Lanka, Vol. 16, Issue 2, July 2012

other students of the same course". The Chi-square test result found to be statistically significant with 6.189 chi-square value and 0.045 p-value (Table 6).

Table 6: 'Gender * E-learning provides opportunities to share and discuss subject matters with other students of the same course' cross tabulation \& $\chi 2$-test result for the cross tabulation

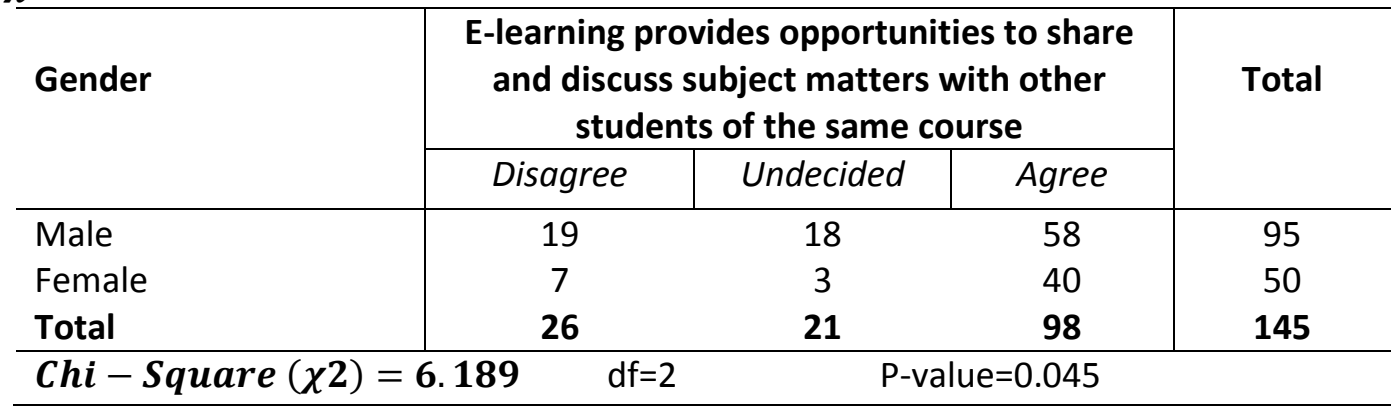

The cross tabulation run between gender and the perceptions for the statement "Overall I have enjoyed learning online" indicated that they are correlated and the chi-square result found to be statistically significant with 8.378 chi-square value and $0.015 p$-value where significance level is 0.05 (Table 7).

Table 7: 'Gender* Overall I have enjoyed learning online' cross tabulation \& $\chi 2$ - test result for the cross tabulation

\begin{tabular}{|c|c|c|c|c|}
\hline \multirow[t]{2}{*}{ Gender } & \multicolumn{3}{|c|}{ Overall I have enjoyed learning online } & \multirow[t]{2}{*}{ Total } \\
\hline & Disagree & Undecided & Agree & \\
\hline Male & \multicolumn{2}{|l|}{28} & 56 & 95 \\
\hline Female & 7 & 14 & 29 & 50 \\
\hline Total & 35 & 25 & 85 & 145 \\
\hline Chi-Square $(\chi 2)=8.378$ & $\mathrm{df}=$ & \multicolumn{2}{|c|}{ P-value $=0.015$} & \\
\hline
\end{tabular}

The post-hoc tests for perceptions vs gender has no statistically significant standardized residuals. The perceptions for these two statements depend to some extent on gender. The effect of the cell(s) for the relationships is weak. 


\section{Relationship between Availability of Computer Facilities vs Students' Perceptions}

More students, (84) 58.0\% stay away from home during their studies and only (61) $42.1 \%$ come from home. The analysis revealed that (55) $37.9 \%$ students depend only on the computer facilities available at the university while (61) $42.1 \%$ students have computer facilities at home. Only twelve (8.3\%) students have computer facilities at home and hostel/boarding place. The relationship exists between the availability of computer facilities and perceptions for the statements "E-learning helps me to learn independently and self motivated", "At present I have skills to learn in an e-learning environment", "Online resources are valuable for learning" and "E-learning provides opportunities to share and discuss subject matters with the other students of the same course". The chisquare test and post-hoc analysis resulted that the perceptions for the statement "Elearning helps me to learn independently and self motivated" depend to some extent on availability of computer facilities having p-value $=0.035<0.05$ (Table 8).

Table 8: 'Computer facilities*e-learning helps me to learn independently and self-motivated' cross tabulation $\& \chi 2$-test result for the cross tabulation

\begin{tabular}{l|ccc|c|}
\hline \multirow{2}{*}{ Computer Facilities } & \multicolumn{3}{|c|}{$\begin{array}{c}\text { E-learning helps me to learn } \\
\text { independently and self-motivated }\end{array}$} & \multirow{2}{*}{ Total } \\
\cline { 2 - 4 } & Disagree & Undecided & Agree & \\
\hline University & 15 & 11 & 29 & 55 \\
At Stay & 12 & 12 & 66 & 90 \\
Total & $\mathbf{2 7}$ & $\mathbf{2 3}$ & $\mathbf{9 5}$ & $\mathbf{1 4 5}$ \\
\hline Chi - Square $(\chi \mathbf{2})=\mathbf{6 . 7 3 1}$ & $\mathbf{d f = 2}$ & \multicolumn{3}{|c|}{ P-value=0.035 } \\
\hline
\end{tabular}

The two variables availability of computer facilities and the perceptions for the statement "At present I have skills to learn in an e-learning environment" are found to be dependent by $p$-value $=0.001<0.05$ (Table 9 ). 
Journal of the University Librarians Association, Sri Lanka, Vol. 16, Issue 2, July 2012

Table 9: 'Computer facilities*At present I have skills to learn in an e-learning environment' cross tabulation $\& \chi 2$-test result for the cross tabulation

\begin{tabular}{l|cc|c|c}
\hline \multirow{2}{*}{ Computer Facilities } & \multicolumn{3}{|c|}{$\begin{array}{c}\text { At present I have skills to learn in an e- } \\
\text { learning environment }\end{array}$} & \multirow{2}{*}{ Total } \\
\cline { 2 - 4 } & Disagree & Undecided & Agree & \\
\hline University & 21 & 8 & 26 & 55 \\
At Stay & 11 & 17 & 62 & 90 \\
Total & $\mathbf{3 2}$ & $\mathbf{2 5}$ & $\mathbf{8 8}$ & $\mathbf{1 4 5}$ \\
\hline Chi - Square $(\boldsymbol{\chi 2})=\mathbf{1 3 . 4 2 6}$ & $\mathrm{df}=2$ & \multicolumn{2}{c}{ P-value=0.001 } \\
\hline
\end{tabular}

The post-hoc analysis between perceptions for the statement "At present I have skills to learn in an e-learning environment" and the availability of computer facilities showed that two cells where standardized residual are $2.5>(+1.96)$ and $-2.0<(-1.96)$ in Disagree row have contributed to the relationship of availability of computer facilities and the perception on the ability to learn in an e-learning environment (Appendix 2-Table II). Within the respondents who use computer facilities at the university there were significantly more students who did not accept that they have skills to learn in an elearning environment.

The $p$-value $=0.004$ less than significance level 0.05 concludes that there exist a relationship between two variables availability of computer facilities and students' perceptions to the statement "Online resources are valuable for learning" (Table 10).

Table 10: 'Computer facilities*Online resources are valuable for learning' cross tabulation $\& \chi 2$-test result for the cross tabulation

\begin{tabular}{l|c|c|c|c}
\hline \multirow{2}{*}{ Computer Facilities } & \multicolumn{3}{|c|}{$\begin{array}{c}\text { Online resources are valuable for } \\
\text { learning }\end{array}$} & \multirow{2}{*}{ Total } \\
\cline { 2 - 4 } & Disagree & Undecided & Agree & \\
\hline University & 12 & 8 & 35 & 55 \\
At Stay & 5 & 8 & 77 & 90 \\
Total & $\mathbf{1 7}$ & $\mathbf{1 6}$ & $\mathbf{1 1 2}$ & $\mathbf{1 4 5}$ \\
\hline Chi - Square $\left(\chi^{2}\right)=10.814$ & $\mathrm{df}=2$ & \multicolumn{2}{c}{ P-value=0.004 } \\
\hline
\end{tabular}


Journal of the University Librarians Association, Sri Lanka, Vol. 16, Issue 2, July 2012

The only one cell where standardized residual is 2.2>+1.96 in 'Disagree' row has resulted the relationship between availability of computer facilities and the perceptions on importance of online resources for learning (Appendix 2-Table II). Within the students who use computer facilities only at the university, there were more students who did not accept that online resources are valuable for learning.

Statistically significant differences were found for the statement "E-learning provides opportunities to share and discuss subject matters with the other students of the same course" across the availability of computer facilities where $p$-value $=0.014<0.05$ (Table 11).

Table 11 : 'Computer facilities*E-learning provides opportunities to share and discuss subject matters with students' cross tabulation \& $\chi^{2}$-test result for the cross tabulation

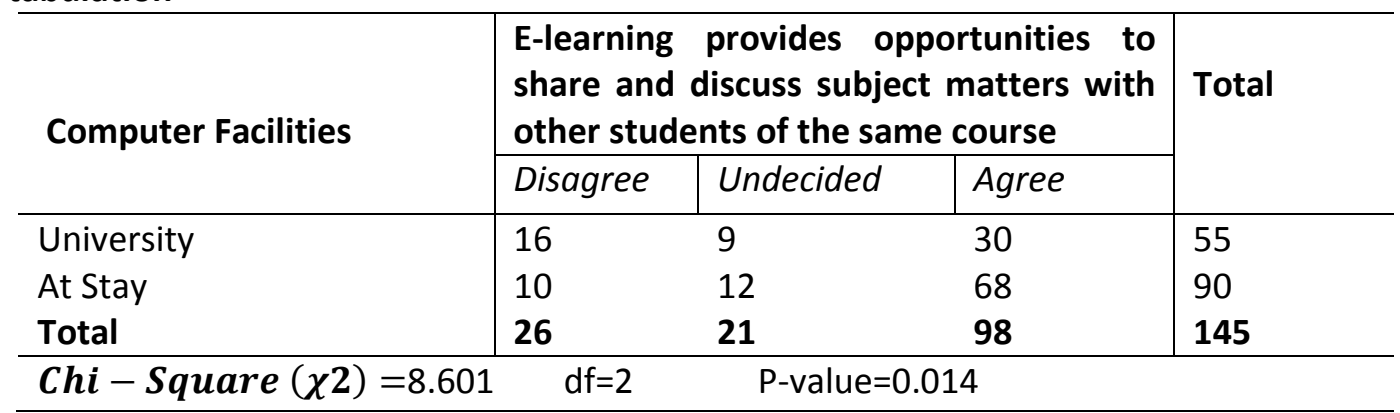

The relationship between availability of computer facilities and the perception of providing opportunities to share and discuss subject matters with other students exists One cell in 'disagree' row has statistically significant standardized residual $2.0>$ critical value $=+1.96$ (Appendix 2-Table II ). More students who use computer facilities only at the university did not accept that e-learning provides opportunities to discuss subject matters with other students.

\section{Relationship between Availability of Internet Facilities vs Students' Perceptions}

A large number of students, (95) 65.5\% use the Internet facilities at the university while (37) $25.5 \%$ students have Internet connection at home. The availability of Internet at both places home and hostel is (1) $0.7 \%$. The analysis supports that there is a difference 
Journal of the University Librarians Association, Sri Lanka, Vol. 16, Issue 2, July 2012

between the students who have Internet at the place of stay during their studies and those who depend only on the Internet facilities of the University when expressing their perceptions for the statement "E-learning makes learning environment too complicated". The resulted chi-square value is 9.455 and p-value is 0.009 at significance level 0.05 (Table 12).

Table 12: 'Internet facilities*E-learning makes learning environment too complicated' cross tabulation $\&(\chi 2)$ - test result for the cross tabulation

\begin{tabular}{|c|c|c|c|c|}
\hline \multirow[t]{2}{*}{ Internet Facilities } & \multicolumn{3}{|c|}{$\begin{array}{c}\text { E-learning makes learning environment } \\
\text { too complicated }\end{array}$} & \multirow[t]{2}{*}{ Tota } \\
\hline & Disagree & Undecided & Agree & \\
\hline University & 46 & 23 & 26 & 95 \\
\hline At Stay & 30 & 17 & 3 & 50 \\
\hline Total & 76 & 40 & 29 & 145 \\
\hline \multicolumn{2}{|c|}{ Chi - Square $(\chi 2)=9.455$} & \multicolumn{2}{|c|}{ P-value $=0.009$} & \\
\hline
\end{tabular}

The post-hoc test revealed that the standardized residuals for the cell for respondents who said that they have Internet facilities at the place of stay during studies and who had the view that "E-learning makes learning environment too complicated" was -2.2 which is smaller than the critical value -1.96 (Appendix 2- Table III). Fewer students who use Internet facilities outside the university said that e-learning makes learning environment too complicated.

The perceptions for the statement "At present I have skills to learn in an e-learning environment" are differed by the availability of Internet facilities for students. The chisquare value is 14.407 and $p$-value is 0.001 (Table 13). 
Journal of the University Librarians Association, Sri Lanka, Vol. 16, Issue 2, July 2012

Table 13: 'Internet facilities*At present I have skills to learn in an e-learning environment' cross tabulation $\& \chi 2$-test result for cross tabulation

\begin{tabular}{l|llll|l}
\hline \multirow{2}{*}{ Internet Facilities } & \multicolumn{3}{|c|}{$\begin{array}{c}\text { At present I have skills to learn } \\
\text { in an e-learning environment }\end{array}$} & \multirow{2}{*}{ Total } \\
\cline { 2 - 4 } & Disagree & Undecided & Agree & \\
\hline University & 29 & 11 & 55 & 95 \\
At Stay & 3 & 14 & 33 & 50 \\
Total & $\mathbf{3 2}$ & $\mathbf{2 5}$ & $\mathbf{8 8}$ & $\mathbf{1 4 5}$ \\
\hline Chi - Square $(\boldsymbol{\chi 2})=\mathbf{1 4 . 4 0 7}$ & $\mathrm{df}=2$ & \multicolumn{2}{c}{ P-value $=0.001$} \\
\hline
\end{tabular}

The standardized residuals for cell for respondents who said that they have Internet facilities at the place of stay during studies and who denied that "At present I have skills to learn in an e-learning environment" was -2.4<-1.96 (Appendix 2-Table III). Fewer students who use Internet facilities outside the university disagree with the above statement.

The Table 14 revealed that availability of Internet facilities and the perceptions to the statement "E-learning provides opportunities to share and discuss subject matters with students of the same course" has an association. The chi-square value is 7.238 and pvalue is 0.027 .

Table 14: 'Internet facilities*E-learning provides opportunities to share and discuss subject matters with the students' cross tabulation \& $\chi 2$-test result for the cross tabulation

\begin{tabular}{l|c|c|c|c}
\hline \multirow{2}{*}{ Internet Facilities } & \multicolumn{2}{|c|}{$\begin{array}{c}\text { E-learning provides opportunities to } \\
\text { share and discuss subject matters with } \\
\text { the students }\end{array}$} & Total \\
\cline { 2 - 4 } & Disagree & Undecided & Agree & \\
\hline University & 21 & 17 & 57 & 95 \\
At Stay & 5 & 4 & 41 & 50 \\
Total & $\mathbf{2 6}$ & $\mathbf{2 1}$ & $\mathbf{9 8}$ & $\mathbf{1 4 5}$ \\
\hline Chi - Square $(\chi \mathbf{2})=\mathbf{7 . 2 3 8}$ & $\mathrm{df}=2$ & P-value=0.027 \\
\hline
\end{tabular}

The analysis confirmed that the perception for the above statements depend to some extent on availability on internal facilities. 


\section{Relationship between Ownership of a Computer vs Students' Perceptions}

Approximately one third of students, (49) $33.8 \%$ do not own a computer. Ninety six (96) $66.3 \%$ students have at least a personal computer or a laptop. There are 11 (7.6\%) students who own both a laptop and a personal computer. The relationships were shown between ownership of a computer and the perceptions of "At present I have skills to learn in an e-learning environment", "Online resources are valuable for learning" and "Elearning provides opportunities to share and discuss subject matters with students of the same course". The chi square values are 9.425, 12.257, 9.122 and p-values are 0.009, 0.002 , and 0.010 respectively at critical value 0.05 (Table 15-17).

Table 15: 'Ownership of a computer*At present I have skills to learn in an e-learning environment' cross tabulation $\& \chi 2$-test result for the cross tabulation

\begin{tabular}{l|ccc|c}
\hline \multirow{2}{*}{ Ownership of a computer } & \multicolumn{2}{|c|}{$\begin{array}{c}\text { At present I have skills to learn } \\
\text { in an e-learning environment }\end{array}$} & \multirow{2}{*}{ Total } \\
\cline { 2 - 4 } & Disagree & Undecided & Agree & \\
\hline No & 18 & 6 & 25 & 49 \\
Yes & 14 & 19 & 63 & 96 \\
Total & $\mathbf{3 2}$ & $\mathbf{2 5}$ & $\mathbf{8 8}$ & $\mathbf{1 4 5}$ \\
\hline $\boldsymbol{C h i}-$ Square $(\boldsymbol{\chi 2})=9.425$ & $\mathrm{df}=2$ & P-value=0.009 \\
\hline
\end{tabular}

Table 16: 'Ownership of a computer* Online resources are valuable for learning' cross tabulation $\& \chi 2$-test result for the cross tabulation

\begin{tabular}{l|cc|c|c}
\hline \multirow{2}{*}{ Ownership of a computer } & \multicolumn{2}{l|}{$\begin{array}{l}\text { Online resources are valuable for } \\
\text { learning }\end{array}$} & \multirow{2}{*}{ Total } \\
\cline { 2 - 4 } & Disagree & Undecided & Agree & \\
\hline No & 12 & 6 & 31 & 49 \\
Yes & 5 & 10 & 81 & 96 \\
Total & $\mathbf{1 7}$ & $\mathbf{1 6}$ & $\mathbf{1 1 2}$ & $\mathbf{1 4 5}$ \\
\hline Chi - Square $(\boldsymbol{\chi 2})=\mathbf{1 2 . 2 5 7}$ & $\mathrm{df}=2$ & \multicolumn{2}{c}{ P-value=0.002 } \\
\hline
\end{tabular}


Journal of the University Librarians Association, Sri Lanka, Vol. 16, Issue 2, July 2012

Table 17: 'Ownership of a computer*E-learning provides opportunities to share and discuss subject matters with students of the same course' cross tabulation \& $\chi 2$ - test result for the cross tabulation

\begin{tabular}{l|c|c|c|c}
\hline \multirow{2}{*}{ Ownership of a computer } & \multicolumn{2}{|l|}{$\begin{array}{l}\text { E-learning provides opportunities to } \\
\text { share and discuss subject matters with } \\
\text { students of the same course }\end{array}$} & \multirow{2}{*}{ Total } \\
\cline { 2 - 4 } & Disagree & Undecided & Agree & \\
\hline No & 15 & 8 & 26 & 49 \\
Yes & 11 & 13 & 72 & 96 \\
Total & $\mathbf{2 6}$ & $\mathbf{2 1}$ & $\mathbf{9 8}$ & $\mathbf{1 4 5}$ \\
\hline Chi-Square $(\chi \mathbf{2})=\mathbf{9 . 1 2 2}$ & $\mathrm{df}=2$ & P-value=0.010 \\
\hline
\end{tabular}

The standardized residuals of the cell for respondents who do not have a computer and disagree with "At present they have skills to learn in an e-learning environment" was 2.2 which is larger than the critical value 1.96 (Appendix 2-Table IV).

The post hoc test between 'online resources are valuable for learning' and ownership of a computer showed that the standardized residuals for the cell for respondents who do not have a computer and disagree with "Online resources are valuable for learning" was 2.6 which is greater than the critical value 1.96 (Appendix 2-Table IV).

Appendix 2 -Table IV revealed that the standardized residual for the cell for respondents who do not have computers and disagree with e-learning provides opportunities to share and discuss subject matter with other students were 2.1 .

More students who do not own a computer disagree with "at present I have skills to learn in an e-learning environment", "Online resources are valuable for learning" and "elearning provides opportunities to share and discuss subject matters with other students" than would be expected. 
Journal of the University Librarians Association, Sri Lanka, Vol. 16, Issue 2, July 2012

\section{Conclusion}

The key findings are: within fourth year students there were more students who are uncertain about the helpfulness of the course management systems in improving exam grades. Among the students who use computer facilities only at the university and who do not own a computer there were more students who have negative perception towards the statements 'At present they have skills to learn in an e-learning environment', 'Online resources are valuable for learning' and 'e-learning provides opportunities to share and discuss subject matters with other students'. Introduction of Information Literacy programmes that improve the knowledge on online resources and skills required to learn in an e-learning environment was suggested. Since students have negative perception on e-learning further research to identify their willingness to embrace e-learning is essential.

\section{References}

Buzzetto-more, N.A. (2008). Student perceptions of various e-learning components. Interdisciplinary. Journal of e-learning and learning objects, 4, 113-134.

Chadha, G. \& Kumail, N. (2003). E-learning: an expression of the knowledge economy. New Delhi : Tata McGraw-Hill Publishing.

Keller, C. \& Cernerud, L. (2002). Student's perceptions of e-learning in university education. Journal of Educational Media, 27(1-2), 55-67. Retrieved from http://education.korea.ac.kr/innwoo/edu603/elearning/Students\%20Perceptions \%20of\%20E- learning\%20in\%20University\%20Education.pdf.

Krejcie, R. V. \& Morgan, D. W. (1970). Determining sample size for research activities. Educational and Phychological Measurement, 30, 607-10.

Mering, J. \& Robbie, D. (2004). Education and electronic learning- Does online learning assist learners and how can it be continuously improved? In Proceedings of HERDSA 2004 conference "Transforming Knowledge into Wisdom: Holistic Approaches to Teaching and Learning" at Miri, Sarawak. Retrieved from http://www.herdsa.org.au/ conference2004/Contributions/NRPapers/A013-jt.pdf

Partridge, H. \& Edwards, S. (2005). Establishing IT Student's Perspective to e-Learning: Preliminary findings from a Queensland University of Technology Case Study In Proceedings of Informing Science and Information Technology Education Joint 
Journal of the University Librarians Association, Sri Lanka, Vol. 16, Issue 2, July 2012

Conference. Flagstaff, Arizona, Brisbane, Queensland University of Technology.

Retrieved from http://eprints.qut.edu.au/archive/00001290/01/

InSite_2005_edwards.pdf

Secker, J. (2004). Electronic resources in virtual learning environment: a guide for Librarians(1st ed.). Oxford: Chandos Publishing.

\section{Appendix 1}

Table 1: Students' Demographic Details

\begin{tabular}{|c|c|c|c|}
\hline \multicolumn{2}{|l|}{ Demographic Data } & \multirow{2}{*}{$\begin{array}{c}\text { Noofrespondents } \\
60\end{array}$} & \multirow{2}{*}{$\begin{array}{c}\begin{array}{c}\text { Percentage } \\
\text { (\%) }\end{array} \\
41.4\end{array}$} \\
\hline Courseenrolled & ICT & & \\
\hline & CS & 85 & 58.6 \\
\hline \multirow[t]{2}{*}{ Gender } & Male & 95 & 65.5 \\
\hline & Female & 50 & 34.5 \\
\hline \multirow[t]{3}{*}{ Year ofStudy } & Second & 69 & 47.6 \\
\hline & Third & 54 & 37.2 \\
\hline & Fourth & 22 & 15.2 \\
\hline Time Spent on Course Management & Notused & 20 & 13.8 \\
\hline \multirow[t]{4}{*}{ System } & 1-3hours & 72 & 49.7 \\
\hline & 4-6hours & 25 & 17.2 \\
\hline & 7-9hours & 17 & 11.7 \\
\hline & 10-more & 11 & 7.6 \\
\hline \multirow[t]{3}{*}{ Place of stay duringstudy } & Home & 61 & 42.1 \\
\hline & Hostel & 22 & 15.2 \\
\hline & Boarding & 62 & 42.8 \\
\hline \multirow[t]{6}{*}{ Availability of computer faailities } & Universityonly & 55 & 37.9 \\
\hline & Home & 61 & 42.1 \\
\hline & Hostel & 4 & 2.8 \\
\hline & Boarding Place & 13 & 9.0 \\
\hline & Home\&Hostel & 2 & 1.4 \\
\hline & Home\& Boarding place & 10 & 6.9 \\
\hline \multirow[t]{6}{*}{ Availability of Intemet facilities } & Universityonly & 95 & 65.5 \\
\hline & Home & 37 & 25.5 \\
\hline & Hostel & 1 & 0.7 \\
\hline & Boarding Place & 4 & 2.8 \\
\hline & Home\&Hostel & 1 & 0.7 \\
\hline & Home\&Boarding & 7 & 4.8 \\
\hline \multirow[t]{4}{*}{ Ownership of computers } & Personal Computer & 71 & 49.0 \\
\hline & Laptop & 14 & 9.7 \\
\hline & PCand Laptop & 11 & 7.6 \\
\hline & Nocomputer & 49 & 33.8 \\
\hline
\end{tabular}




\section{Appendix 2}

Table I: Post-hoc Analysis on Students' Perceptions vs Year of Study

\begin{tabular}{llccc}
\hline & & \multicolumn{3}{c}{ Standardized Residuals } \\
\cline { 3 - 5 } & & \multicolumn{3}{c}{ Year ofStudy } \\
& & Second & Third & Fourth \\
\hline TheCMShelpsin improving examgrades & Disagree & -0.8 & 1.2 & -0.4 \\
& Undecided & -0.8 & -0.5 & 2.3 \\
& Agree & 1.3 & -0.2 & -1.9 \\
\hline
\end{tabular}

Table II: Post-hoc Analysis on Students' Perceptions vs Availability of Computer Facilities

\begin{tabular}{l|lccc}
\hline & & \multicolumn{2}{c}{ Standardized Residuals } \\
\cline { 3 - 4 } & & \multicolumn{2}{c}{ Computer Facilities } \\
& & University & AtStay \\
\hline AtpresentIhave skillsto leam in an elearning environment & Disagree & 2.5 & -2.0 \\
& Undecided & -0.5 & 0.4 \\
& Agree & -1.3 & 1.0 \\
\hline Online resourcesarevaluableforlearning & Disagree & 2.2 & -1.7 \\
& Undecided & 0.8 & -0.6 \\
\hline E-teaming provides opportunities to share and discuss subject matters & Agree & -1.1 & 0.9 \\
with otherstudents ofthesamecourse & Disagree & 2.0 & -1.5 \\
& Undecided & 0.4 & -0.3 \\
& Agree & -1.2 & 0.9 \\
\hline
\end{tabular}

Table III: Post-hoc Analysis on Students' Perceptions vs Availability of Internet Facilities

\begin{tabular}{|c|c|c|c|}
\hline & & \multirow{2}{*}{\multicolumn{2}{|c|}{$\begin{array}{c}\text { Standardized Residuals } \\
\text { IntemetFacilities }\end{array}$}} \\
\hline & & & \\
\hline & & University & AtStay \\
\hline \multirow[t]{3}{*}{ E-leaming makesleamingenvironment too complicated } & Disagree & -0.5 & 0.7 \\
\hline & Undecided & -0.6 & 0.9 \\
\hline & Agree & 1.6 & -2.2 \\
\hline \multirow[t]{3}{*}{ Atpresent Ihave skillstolearn in aneleaming environment } & Disagree & 1.8 & -2.4 \\
\hline & Undecided & -1.3 & 1.8 \\
\hline & Agree & -0.3 & 0.5 \\
\hline
\end{tabular}


Journal of the University Librarians Association, Sri Lanka, Vol. 16, Issue 2, July 2012

Table IV: Post-hoc Analysis on Students' Perceptions vs Ownership of Computer

\begin{tabular}{|c|c|c|c|}
\hline & & \multicolumn{2}{|c|}{ Standardized Residuals } \\
\hline & & \multicolumn{2}{|c|}{ Ownership of Compute } \\
\hline & & No & Yes \\
\hline \multirow[t]{3}{*}{ Atpresentlhaveskillstoleam in ane-learningenvironment } & Disagree & 2.2 & -1.6 \\
\hline & Undecided & -0.8 & 0.6 \\
\hline & Agree & -0.9 & 0.6 \\
\hline \multirow[t]{2}{*}{ Online resources are valuablefor learning } & $\begin{array}{l}\text { Disagree } \\
\text { Undecided }\end{array}$ & $\begin{array}{l}2.6 \\
0.3\end{array}$ & $\begin{array}{l}-1.9 \\
-0.2\end{array}$ \\
\hline & Agree & -1.1 & 0.8 \\
\hline \multirow{3}{*}{$\begin{array}{l}\text { E-eaming provides opportunities to share and discuss subject } \\
\text { matter with other students of the same course }\end{array}$} & Disagree & 2.1 & -1.5 \\
\hline & Undecided & 0.3 & -0.2 \\
\hline & Agree & -1.2 & 0.9 \\
\hline
\end{tabular}

